\title{
Somatic Cell Count Distributions During Lactation Predict Clinical Mastitis
}

\author{
M. J. Green, ${ }^{1}$ L. E. Green, ${ }^{1}$ Y. H. Schukken, ${ }^{2}$ A. J. Bradley, ${ }^{3}$ E. J. Peeler, ${ }^{4}$ \\ H. W. Barkema, ${ }^{5}$ Y. de Haas, ${ }^{6}$ V. J. Collis, ${ }^{1}$ and G. F. Medley ${ }^{1}$ \\ ${ }^{1}$ Ecology and Epidemiology Group, Department of Biological Sciences, \\ University of Warwick, Coventry, CV4 7AL, UK \\ ${ }^{2}$ Department of Population Medicine and Diagnostic Sciences, \\ College of Veterinary Medicine, Cornell University, Ithaca, NY 14853 \\ ${ }^{3}$ Department of Clinical Veterinary Science, University of Bristol, \\ Langford House, Langford, Bristol, BS40 5DT, UK \\ ${ }^{4}$ Centre for Environment, Fisheries, Aquaculture Science, \\ Barrack Road, The Nothe, Weymouth, DT4 8UB, UK \\ ${ }^{5}$ Dept. of Health Management, Atlantic Veterinary College, \\ University of Prince Edward Island, 550 University Avenue, \\ Charlottetown, PEI, 4P3 C1A Canada \\ ${ }^{6}$ Institute for Animal Science and Health (ID-Lelystad), \\ NL-8200 AB Lelystad, The Netherlands
}

\begin{abstract}
This research investigated somatic cell count (SCC) records during lactation, with the purpose of identifying distribution characteristics (mean and measures of variation) that were most closely associated with clinical mastitis. Three separate data sets were used, one containing quarter SCC $(\mathrm{n}=1444)$ and two containing cow SCC ( $\mathrm{n}=933$ and 11,825$)$. Clinical mastitis was defined as a binary outcome, present or absent, for each lactation, and SCC were log (base 10) transformed. A generalized linear mixed model within a Bayesian framework was used for analysis. Parameters were estimated using Markov Chain Monte Carlo with Gibbs sampling. Results from the 3 data sets were similar. Increased maximum and standard deviation log SCC during lactation, rather than increased geometric mean, were the best overall indicators of clinical mastitis. Distributions of SCC were also investigated separately for different mastitis pathogens. Increased maximum log SCC was associated with clinical mastitis caused by all pathogen types. Increased standard deviation $\log$ SCC was associated with Staphylococcus aureus, and Streptococcus uberis clinical mastitis and increased coefficient of variation log SCC (standard deviation divided by mean) was associated with Escherichia coli clinical mastitis. Increased geometric mean lactation SCC was associated with an increased risk of Staph. aureus clinical mastitis but a reduced risk of $E$. coli clinical mastitis.
\end{abstract}

Received April 24, 2003.

Accepted September 22, 2003.

Corresponding author: M. J. Green; e-mail: martingreen1000@ ntlworld.com.
Our results suggest that using measures of variation and maximum cow SCC would enhance the accuracy of predicting clinical mastitis, compared with geometric mean SCC, and therefore improve genetic programs that aim to select for clinical mastitis resistance. The results are also consistent with low SCC increasing susceptibility to some mastitis pathogens.

(Key words: mastitis, somatic cell count)

Abbreviation key: $\mathbf{C M}=$ clinical mastitis, $\mathbf{C S C C}=$ cow SCC, QSCC = quarter SCC.

\section{INTRODUCTION}

Clinical mastitis ( $\mathbf{C M})$ is an important cause of disease in dairy cattle and continues to place a major financial burden on the UK dairy industry (Kossaibati and Esselmont, 1997). The control of mastitis involves management procedures and treatments to control pathogen transmission (Dodd et al., 1969) and measures to reduce cow susceptibility, such as optimal nutrition (Weiss et al., 1997; van Werven, 1999) vaccination (Gonzalez et al., 1989), and breeding for disease resistance (Shook and Schultz, 1994).

Genetic evaluation programs for mastitis are widespread, although the traits used for evaluations differ slightly between countries (Mark et al., 2002). Denmark, Sweden and Finland use cow CM records and SCC data to calculate genetic indices, whereas other countries, including France, The Netherlands, the United Kingdom, and the United States use cow SCC (CSCC) information alone. Genetic evaluations using CSCC are based on log-transformed test-day CSCC records or the mean of logged test-day records during lactation. 
Somatic cell counts are therefore used widely in genetic programs as a proxy for clinical and subclinical IMI. The correlation between lactation mean SCC and $\mathrm{CM}$ has been reported to be positive and linear (Philipsson et al., 1995). Estimates of this correlation vary and have been estimated at 0.3 (Weller et al., 1992), 0.6 (Emanuelson et al., 1988), and 0.79 (Philipsson et al., 1995). The correlation between somatic cell production deviance (a measure of the mean difference in somatic cell production from an expected uninfected cow, corrected for stage of lactation) and CM has been reported to be 0.80 (Lund et al., 1999).

One of the potential shortcomings of breeding for clinical mastitis resistance using SCC was pointed out by Shook (1993). Because most cell counting programs observe SCC at approximately monthly intervals, acute, short-lasting infections may be difficult to identify from increased mean SCC during lactation. It is apparent that different mastitis pathogens elicit different SCC responses (de Haas et al., 2002) and in particular that CM associated with 'environmental' organisms, such as $E$. coli may result in a high SCC for a short period of time (van Werven, 1999; de Haas et al., 2002).

It may be possible to improve the prediction of $\mathrm{CM}$ from SCC by using characteristics of SCC distributions, other than the lactation mean. For example, a method was recently described that assessed the effect of pathogen-specific CM on the lactation curve for SCC (de Haas et al., 2002). In the present study we have investigated SCC distributions during lactation with the purpose of identifying the characteristics most closely associated with CM. Analysis was carried out in a Bayesian context and model parameters were estimated using Markov Chain Monte Carlo with Gibbs sampling.

\section{MATERIALS AND METHODS}

Quarter SCC (QSCC) or CSCC from 3 separate data sets were used in the analysis. In each set of data, lactations with and without CM were identified from prospectively collected records.

\section{Data Set 1}

Three commercial dairy herds in Southwest England participated, each with 120 to 180 Holstein/Friesian cows. During the study, annual milk yields ranged from 6000 to $7500 \mathrm{~kg}$ per cow, and the monthly bulk milk SCC ranged from 60,000 to $200,000 / \mathrm{mL}$. Quarter milk samples were collected as a part of a previous prospective study (Peeler et al., 2003). Milk samples were taken at a morning milking, every 4 to $6 \mathrm{wk}$, for $12 \mathrm{mo}$ and submitted to an accredited laboratory (On Merit, Newbury, Berkshire, UK) for automatic somatic cell count- ing. The electronic cell counter was standardized using recognized European cell count standard samples (Centre D'etude et de controle des analyses en industrie laitiere, France) and checked for recalibration after every 20 cell count measurements. Clinical mastitis was identified and recorded by herdsmen on each farm.

\section{Data Set 2}

Data from 5 commercial dairy herds in Gloucestershire, UK, comprised this data set, and data collection has been described previously (Hedges et al., 2001). The herds contained between 100 and 250 cows each and had bulk milk SCC in the range of 100,000 to 250,000/ $\mathrm{mL}$. The CSCC were measured from pooled quarter milk samples taken from each cow, approximately monthly, between June 1997 and April 1999, as a part of a national commercial milk recording program (National Milk Records, Chippenham, UK). Clinical mastitis was identified and recorded prospectively by the herdsmen.

\section{Data Set 3}

These data came from 274 Dutch dairy herds. The herds participated in a national SCC recording scheme and have been described previously by Barkema et al. (1998). The CSCC was measured every 3 to $4 \mathrm{wk}$ and CM was identified and recorded by the herdsmen. Concurrent CM and SCC records were available for analysis from December 1992 until June 1994. Aseptic milk samples were collected from cases of CM (Barkema et al., 1998) and bacterial culture and identification carried out using standard techniques (Harmon et al., 1990).

\section{Analysis}

In data sets 2 and 3, complete lactations that had a minimum of 5 SCC readings were used for analysis. A lactation started on the date of calving and ended either at the date of drying off or of culling. In data set 1 , because data collection was only performed for $1 \mathrm{yr}$, lactations with 5 or more SCC readings were included, whether or not they were whole lactations.

Clinical mastitis was defined as a binary outcome, present or absent, for each lactation. Therefore, a lactation with $\mathrm{CM}$ had one or more clinical episodes. For pathogen analysis in data set 3 , a lactation was defined as having a case of CM caused by a specific pathogen when all the cases during that lactation were caused by that one pathogen (identified in pure culture). Lactations with mixed causes of CM were omitted from the pathogen-specific analysis.

Individual quarter and CSCC were log (base 10) transformed to normalize the data. The lactation char- 
acteristics of SCC investigated were minimum, maximum, mean, standard deviation, variance, and coefficient of variation (standard deviation/mean) of logtransformed SCC. These SCC characteristics were compared between lactations with and without CM. A further comparison was made between lactations with specific bacterial causes of $\mathrm{CM}$ and unaffected lactations.

\section{Modeling Strategy}

A generalized linear mixed model (GLMM) (Breslow and Clayton, 1993; Burton et al., 1999) within a Bayesian framework was used for modeling CM. Models were specified in the following manner (Zeger and Karim, 1991; Burton et al., 1999):

$$
\begin{gathered}
\operatorname{logit}\left(\mu_{\mathrm{ij}}\right)=\alpha+\beta_{1 \mathrm{ij}}^{\prime}+X_{1 \mathrm{ij}}+\beta^{\prime}{ }_{\mathbf{2 j}} X_{2 \mathrm{j}} \ldots \ldots+\mathrm{v}_{\mathrm{j}}+\mathrm{u}_{\mathrm{ij}} \\
\mathrm{CM}_{\mathrm{ij}} \sim \text { Bernoulli distribution, }
\end{gathered}
$$

where the subscripts $i$ and $j$ denote the ith (lowest) level data points clustered within the jth (second) level, respectively. $\mathrm{i}$ and $\mathrm{j}$ were either quarter lactations within cows (data set 1), cow lactations within cows (data set 2), or cow lactations within farms (data set 3 ).

$$
\begin{aligned}
& \mathrm{CM}_{\mathrm{ij}}=\text { the binary response denoting mastitis in } \\
& \mu_{\mathrm{ij}}=\text { the fitted probability of } \mathrm{CM} \text { in the ith lac- } \\
& \text { tation of the jth cluster. } \\
& \alpha=\text { intercept } \\
& \mathbf{X}_{1 \mathrm{ij}}=\text { vector of covariates associated with lacta- } \\
& \text { tion i within cluster } \mathrm{j} \text {. } \\
& \boldsymbol{\beta}^{\prime}{ }_{1 \mathrm{ij}}=\text { transposed vector of coefficients for } \mathrm{X}_{1 \mathrm{ij}} \text {. } \\
& \mathbf{X}_{2 \mathbf{j}}=\text { vector of } \mathrm{j} \text {-level exposures for each cluster, } \\
& \mathrm{j} \text {. } \\
& \boldsymbol{\beta}^{\prime}{ }_{2 \mathrm{j}}=\text { transposed vector of coefficients for } \mathrm{X}_{2 \mathrm{j}} \text {. } \\
& \mathrm{v}_{\mathrm{j}}=\text { random effect reflecting residual error be- } \\
& \text { tween clusters j. } \\
& \mathrm{u}_{\mathrm{ij}}=\text { random effect reflecting residual error be- } \\
& \text { tween lactations. }
\end{aligned}
$$

Scientific interest focused on the relationship between minimum, maximum, mean, standard deviation, variance, and coefficient of variation log SCC and CM. These covariates were initially modeled in quintiles of increasing magnitude and only included as continuous variables when the relationship with $\mathrm{CM}$ was linear. Interactions were tested between significant covariates. Farm (data sets 1 and 2), parity, calving month, mean DIM of SCC recordings and quarter position (data set 1 ), were modeled as fixed effects in the models and included if they influenced the relationship between SCC and CM (Hosmer and Lemeshow, 1988). In a few instances in data sets 1 and 3, cows contributed more than one lactation to the analysis, because they were dried off and calved again within the period of data collection. Because this second lactation was a rare event, a binary variable was introduced for 'second lactation' and modeled as a fixed effect. In data set 2, second lactations during the study were modeled as random variables, because their frequency was relatively high. In data set 3 , farm was fitted as a random effect.

Model building was exploratory and initial models were investigated in MLwiN (version 1.10.0006, Rasbash et al., 2000). Final models were constructed using Markov Chain Monte Carlo with Gibbs sampling (Gilks et al., 1995) in WinBUGS (Version 1.3, Spiegelhalter et al., 2000). Vague prior distributions were specified for unbounded fixed effects $(\sim$ Normal [mean $=0$, variance $=$ $\left.10^{6}\right]$ ) and for random effect variances ( Gamma [mean= 0.001 , variance $\left.=10^{3}\right]$ ). Although such prior distributions have to be used with caution when data is sparse, in this study, data were plentiful. Therefore, by specifying vague prior distributions, parameters were estimated essentially from characteristics of the data, without the influence of previous belief.

Three simultaneous Markov chains were run for each model to enable the monitoring of both mixing and convergence (Gilks et al., 1995). Convergence of the chains was considered to have occurred when the Gelman Rubin statistic approached 1.00 for normally distributed model parameters (Brooks and Gelman, 1998), and when the traces were visually stable (Gilks et al., 1995). Iterations in the chain up to this point ('burn-in') were not used for parameter estimates (Gilks et al., 1995). Chains were then run for a minimum of 7000 further iterations each, and the posterior means and $95 \%$ credibility intervals (range within which there was a $95 \%$ probability of true mean falling) of parameters were derived from these iterations. Model parameter distributions were assessed using kernel density plots, and covariate odds ratios were considered significant when the $95 \%$ credibility interval did not include 1.00 .

Model fit was assessed from Pearson residuals, where

Pearson residual $=\{$ Observed value - fitted value $\} /$ \{square root (fitted value x (1 - fitted value))\}.

Pearson residuals were plotted against fitted values to check that the mean of aggregations of these residuals approximated to zero (McCullagh and Nelder, 1989). The influence of outlying points was investigated by reanalyzing the data with their omission, to assess whether parameter estimates changed (McCullagh and Nelder, 1989). 
Table 1. Numbers in the table describe the antilog of the mean log transformed SCC parameters, across all lactations within each specified group.

\begin{tabular}{|c|c|c|c|c|c|c|}
\hline & \multicolumn{2}{|c|}{ Date set 1} & \multicolumn{2}{|c|}{ Data set 2} & \multicolumn{2}{|c|}{ Data set 3} \\
\hline & $\begin{array}{l}\text { No } \mathrm{CM}^{1} \\
\mathrm{n}=1344\end{array}$ & $\begin{array}{l}\mathrm{CM} \\
\mathrm{n}=100\end{array}$ & $\begin{array}{l}\text { No CM } \\
\mathrm{n}=804\end{array}$ & $\begin{array}{l}\mathrm{CM} \\
\mathrm{n}=128\end{array}$ & $\begin{array}{l}\text { No CM } \\
\mathrm{n}=9831\end{array}$ & $\begin{array}{l}\mathrm{CM} \\
\mathrm{n}=1994\end{array}$ \\
\hline Mean test-day SCC & 22,776 & 39,995 & 54,515 & 100,800 & 81,935 & 148,738 \\
\hline Minimum test-day SCC & 5558 & 6961 & 20,585 & 27,182 & 26,830 & 38,752 \\
\hline Maximum test-day SCC & 104,630 & 299,167 & 172,935 & 614,567 & 266,168 & 701,071 \\
\hline
\end{tabular}

${ }^{1} \mathrm{CM}=$ Clinical mastitis.

\section{RESULTS}

\section{Data Set 1}

A total of 1444 quarter lactations from 353 cows were used for analysis. Clinical mastitis occurred in 100 (6.9\%) quarter lactations from $82(23.3 \%)$ cows. The mean number of QSCC records per quarter lactation was 6.67 .

\section{Data Set 2}

Cow lactations $(\mathrm{n}=932)$ from 733 cows were used for analysis. Clinical mastitis occurred in 128 (13.7\%) cow lactations from 118 (16.1\%) cows. The mean number of QSCC records per lactation was 7.59.

\section{Data Set 3}

A total 11,825 cow lactations from 11,673 cows were included in the analysis. Clinical mastitis occurred in 1994 (16.9\%) cow lactations from 1993 (17.1\%) cows. The mean number of QSCC records per lactation was 9.85 .

Pathogen-specific models were constructed for clinical mastitis caused by Staphylococcus aureus $(\mathrm{n}=206)$, Streptococcus dysgalactiae ( $=96)$, Streptococcus $u b$ eris $(\mathrm{n}=81)$, Escherichia coli $(\mathrm{n}=310)$, and clinical mastitis associated with no bacterial growth $(\mathrm{n}=242)$.

\section{Description of SCC Distributions in Lactations With and Without CM}

Features of SCC distributions in lactations with and without CM are shown in Tables 1 and 2. Quarter SCC in data set one tended to be lower and more variable during lactation than CSCC in data sets 2 and 3. The effect of CM on SCC, however, was similar in the 3 data sets. Overall, lactations with CM had numerically higher mean, minimum, maximum, standard deviation, variance, and coefficient of variation of $\log$ SCC than lactations without CM. The increase in maximum, standard deviation, and variance of log SCC was proportionately greater, than in mean or minimum log SCC.

Somatic cell count characteristics during lactations associated with different mastitis pathogens are presented in Table 3 and Figure 1. There was a numerical increase in maximum, standard deviation, and variance $\log$ SCC in lactations associated with all pathogen-specific CM, compared with unaffected lactations. There was also an increase in mean and minimum lactation log SCC associated with all pathogen-specific CM, although this increase was relatively small for CM associated with $E$. coli or no bacterial growth.

\section{Models of all Clinical Mastitis}

The models for all CM (models 1, 2, and 3) are presented in Table 4. Having controlled for confounding

Table 2. Log SCC distributions between lactations with and without clinical mastitis.

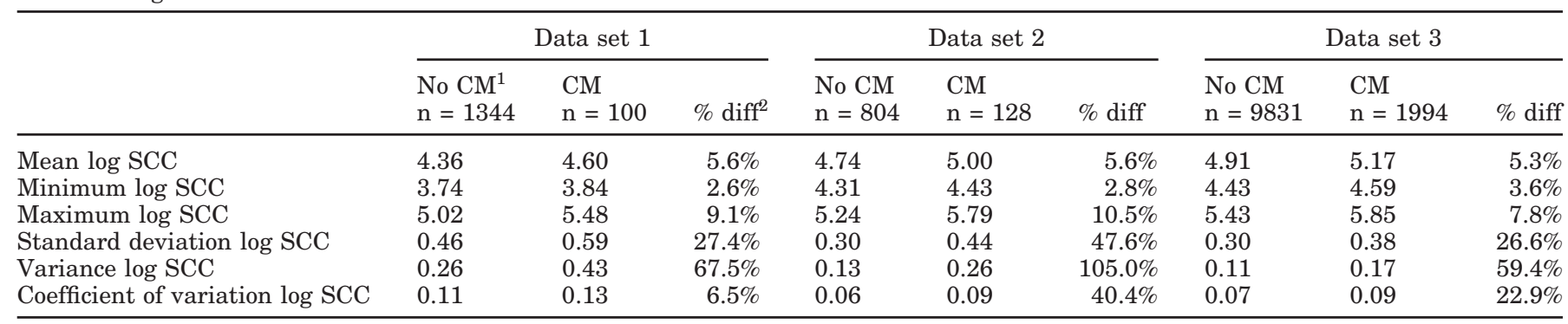

${ }^{1} \mathrm{CM}=$ Clinical mastitis.

${ }^{2} \%$ diff $=$ Percentage difference between lactations with and without clinical mastitis . 
Table 3. Log SCC distributions in lactations with and without clinical mastitis caused by specific pathogens (data set 3).

\begin{tabular}{|c|c|c|c|c|c|c|c|c|c|c|c|}
\hline \multirow[b]{3}{*}{$\mathrm{n}$} & \multirow{3}{*}{$\begin{array}{l}\text { No } \\
\mathrm{CM}^{1} \\
9831\end{array}$} & \multicolumn{10}{|c|}{ Pathogen-specific clinical mastitis } \\
\hline & & \multicolumn{2}{|c|}{ E. coli } & \multicolumn{2}{|c|}{ No growth } & \multicolumn{2}{|c|}{$\begin{array}{c}\text { Streptococcus } \\
\text { uberis }\end{array}$} & \multicolumn{2}{|c|}{$\begin{array}{c}\text { Streptococcus } \\
\text { dysgalactiae }\end{array}$} & \multicolumn{2}{|c|}{$\begin{array}{c}\text { Staphylococcus } \\
\text { aureus }\end{array}$} \\
\hline & & Mean & $\%^{2}$ & Mean & $\%$ & Mean & $\%$ & Mean & $\%$ & Mean & $\%$ \\
\hline Mean log SCC & 4.91 & 4.99 & 1.6 & 5.00 & 1.8 & 5.22 & 6.3 & 5.26 & 7.0 & 5.36 & 9.1 \\
\hline Variance log SCC & 0.11 & 0.16 & 48.0 & 0.16 & 43.7 & 0.17 & 51.7 & 0.18 & 67.6 & 0.17 & 57.1 \\
\hline Coefficient of variation log SCC & 0.07 & 0.08 & 17.1 & 0.08 & 19.7 & 0.08 & 19.1 & 0.09 & 24.6 & 0.08 & 18.4 \\
\hline
\end{tabular}

${ }^{1} \mathrm{CM}=$ Clinical mastitis.

$2 \%=$ Percentage difference between lactations with and without clinical mastitis.

covariates, an increase in maximum and standard deviation log SCC was associated with an increased probability of $\mathrm{CM}$ in all 3 data sets. An increase in minimum $\log$ SCC was associated with an increased risk of CM in data set 1 (model 1). The mean log SCC was not retained in any of the models.

There were no significant interaction terms, and analysis of Pearson residuals suggested the models were of good fit.

\section{Models of Pathogen-Specific Clinical Mastitis}

The final models are presented in Tables 5 and 6 . Having controlled for confounding covariates, maxi-

\begin{tabular}{|ll|}
\hline E. coli & $\square$ No growth \\
四 Streptococcus uberis & 盂 Streptococcus dysgalactiae \\
$\square$ Staphylococcus aureus & \\
\hline
\end{tabular}

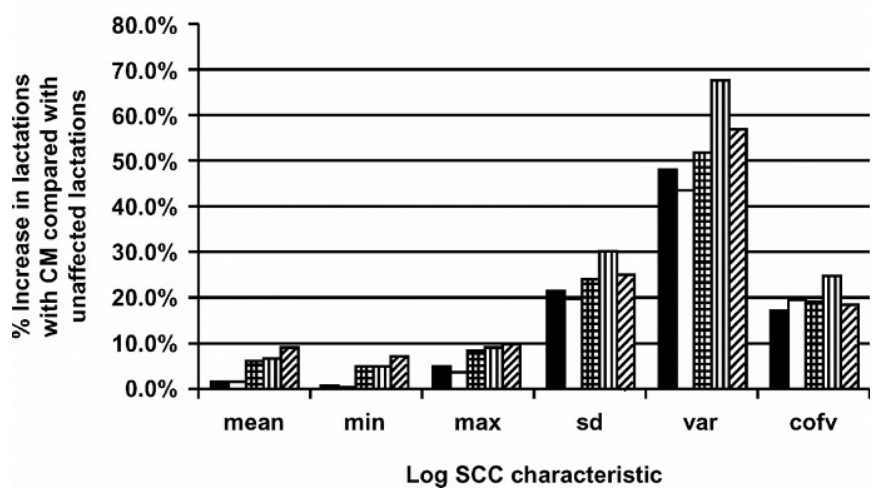

Figure 1. Histogram illustrating the proportional differences in lactation log SCC characteristics (data set 3), between lactations with pathogen-specific clinical mastitis and lactations without clinical mastitis. mean - Geometric mean lactation SCC; $\min$ - minimum lactation log SCC, max - maximum lactation log SCC, sd - standard deviation lactation log SCC, var - variance lactation log SCC, cofv coefficient of variation lactation log SCC. mum log SCC was the parameter most consistently associated with CM, and it was positively associated with $\mathrm{CM}$ in all pathogen-specific models. Increased variability of $\log$ SCC (measured as either standard deviation or coefficient of variation) was associated with an increased likelihood of CM in the Staph. aureus, $E$. coli and Strep. uberis models.

Increasing mean log SCC was associated with an increased probability of clinical mastitis associated with Staph. aureus but with a reduced probability of CM associated with $E$. coli or no bacterial growth. An increase in minimum SCC was associated with an increased likelihood of clinical E. coli and Strep. uberis mastitis.

There were no significant interactions in these models, and analysis of Pearson residuals also suggested the models fitted well.

\section{DISCUSSION}

Somatic cell counts are a useful measure of udder health, because they are widely recorded and accessible for appraisal. The importance of this research is that it suggests some limitations of using lactation mean $\log$ SCC as an indicator of CM, although the trait is currently widely used in genetic evaluation programs (Swanson et al., 1998; Mark et al., 2002). Making better use of patterns or measures of distributions of SCC records may therefore improve genetic programs that aim to select for $\mathrm{CM}$ resistance.

Furthermore, pathogen differences in distributional measures of SCC associated with CM has implications for local mastitis control. It may be possible to identify farms or periods of time when some SCC patterns (and hence pathogens) predominate, and therefore indicate areas of control that should be addressed.

Results from this analysis suggest that maximum and standard deviation of lactation log SCC improve 
Table 4. General linear mixed models for all clinical mastitis in data sets 1, 2, and 3. Parameters were estimated using Markov Chain Monte Carlo with Gibbs sampling.

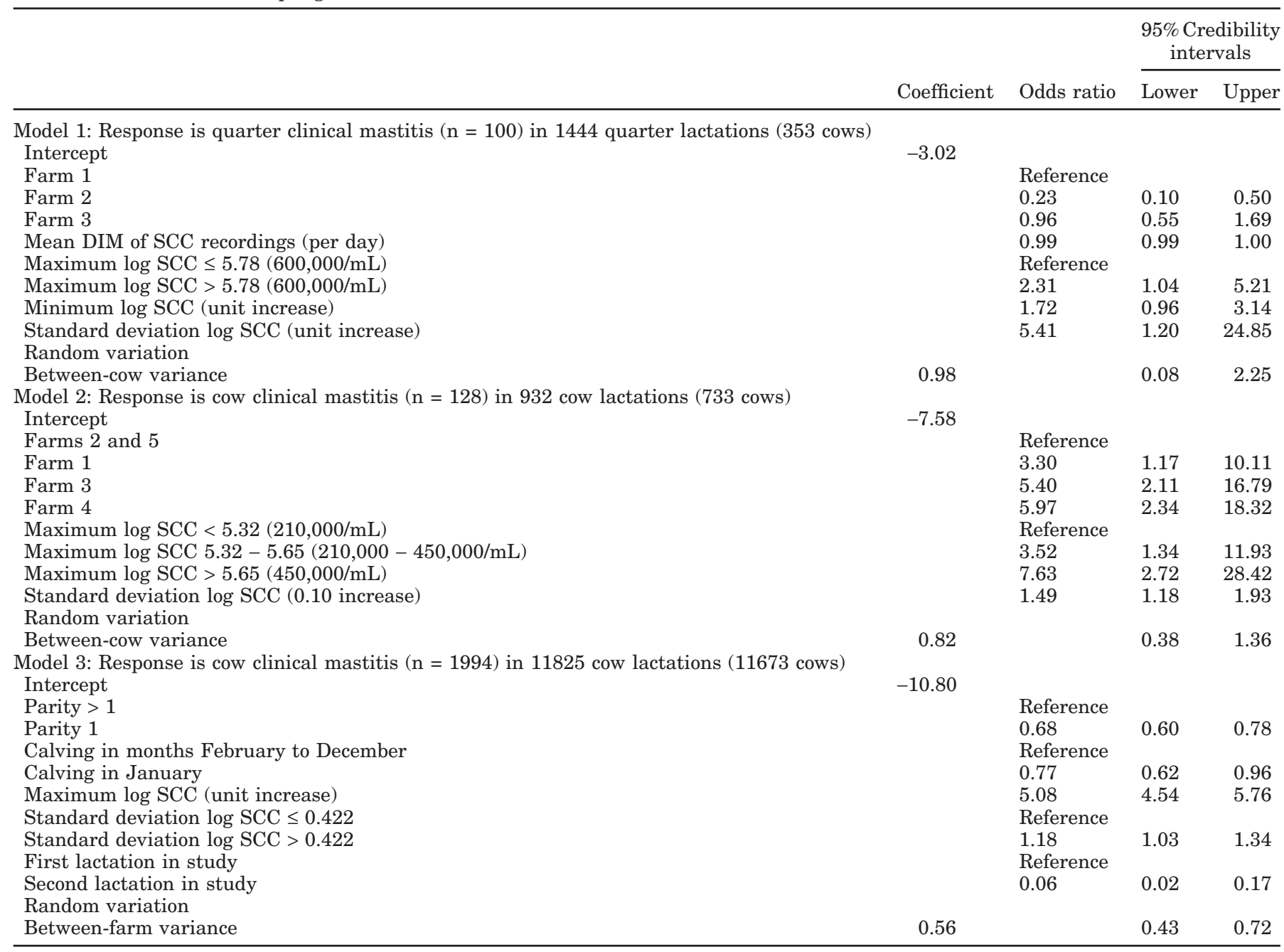

the prediction of $\mathrm{CM}$ compared with using geometric mean SCC. The results were consistent across the 3 data sets, despite the differences between lactation definition (whole or part lactations used), SCC sample type (quarter or cow), geographical location (United Kingdom or The Netherlands), or the size of data set ( $\mathrm{n}=932$ to 11,825 ).

Maximum and standard deviation log SCC were more closely associated with CM than mean log SCC. This may be because these characteristics more accurately describe the effect of clinical IMI on SCC. Somatic cell count rises dramatically following bacterial infection (Shuster et al., 1996; van Werven, 1999) and may return to normal in days or weeks (Milner et al., 1997). Therefore the impact of infection on maximum SCC is likely to be greater than that on mean SCC because the mean is influenced by all SCC readings during lactation, many of which may be taken when there is no inflammatory process.
Increased standard deviation of SCC during lactation was also associated with CM. Variability in SCC during lactation may occur if there is a recrudescence of an initial infection or a new infection later in lactation, or it could be caused by a series of smaller challenges (and therefore SCC responses) in susceptible quarters. Again, these features are more likely to be accurately described by variability in SCC than mean or individual test day SCC. From these results, modeling variation may improve the accuracy of identifying cows with CM and, this warrants continued investigation.

The differences in SCC distributions between pathogens in data set 3 indicate there were clear differences in the behaviour of organisms causing CM. There was a negative association between mean log SCC and CM in the E. coli and "no growth" CM models. This shows, that after accounting for the maximum SCC during lactation, cows that were more likely to get these types of CM had a lower mean lactation SCC than cows that 
Table 5. General linear mixed models for Staphylococcus aureus, Streptococcus dysgalactiae, and Streptococcus uberis clinical mastitis in data set 3. Parameters were estimated using Markov Chain Monte Carlo with Gibbs sampling.

\begin{tabular}{|c|c|c|c|c|}
\hline & \multirow[b]{2}{*}{ Coefficient } & \multirow[b]{2}{*}{ Odds ratio } & \multicolumn{2}{|c|}{$\begin{array}{l}95 \% \text { Credibility } \\
\text { intervals }\end{array}$} \\
\hline & & & Lower & Upper \\
\hline \multicolumn{5}{|l|}{ Model: Staph. aureus clinical mastitis $(\mathrm{n}=206)$} \\
\hline Intercept & -15.47 & & & \\
\hline Parities 2 and $>3$ & & Reference & & \\
\hline Parity 1 & & 1.61 & 1.10 & 2.34 \\
\hline Parity 3 & & 1.70 & 1.17 & 2.44 \\
\hline Mean log SCC (unit increase) & & 7.53 & 4.46 & 12.92 \\
\hline Maximum $\log \mathrm{SCC}<5.56(360,000 / \mathrm{mL})$ & & Reference & & \\
\hline Maximum log SCC $=5.56-5.97(360,000-930,000 / \mathrm{mL})$ & & 2.05 & 1.25 & 3.34 \\
\hline Maximum log SCC $\geq 5.97(930,000 / \mathrm{mL})$ & & 2.63 & 1.42 & 4.82 \\
\hline Standard deviation log SCC $\leq 0.422$ & & Reference & & \\
\hline Standard deviation log SCC > 0.422 & & 1.91 & 1.33 & 2.74 \\
\hline First lactation in study & & Reference & & \\
\hline Second lactation in study & & 0.08 & 0.00 & 0.55 \\
\hline Random variation & & & & \\
\hline Between-farm variance & 0.84 & & 0.40 & 1.42 \\
\hline \multicolumn{5}{|l|}{ Model: Strep. dysgalactiae clinical mastitis $(\mathrm{n}=96)$} \\
\hline Intercept & -6.10 & & & \\
\hline Parities1, 2, and $>3$ & & Reference & & \\
\hline Parity 3 & & 0.47 & 0.23 & 0.88 \\
\hline Maximum $\log \mathrm{SCC}<5.56(360,000 / \mathrm{mL})$ & & Reference & & \\
\hline Maximum log SCC $=5.56-5.97(360,000-930,000 / \mathrm{mL})$ & & 5.47 & 3.04 & 10.07 \\
\hline Maximum log SCC > $5.97(930,000 / \mathrm{mL})$ & & 8.21 & 4.77 & 14.69 \\
\hline Random variation & & & & \\
\hline Between-farm variance & 0.57 & & 0.02 & 1.27 \\
\hline \multicolumn{5}{|l|}{ Model: Strep. uberis clinical mastitis $(\mathrm{n}=81)$} \\
\hline Intercept & -6.16 & & & \\
\hline Calving in months other than March, and August & & Reference & & \\
\hline Calving in March & & 2.00 & 1.00 & 3.73 \\
\hline \multicolumn{5}{|l|}{ Calving in May } \\
\hline \multicolumn{5}{|l|}{ Calving in August } \\
\hline Maximum $\log \mathrm{SCC} \leq 5.97(930,000 / \mathrm{mL})$ & & Reference & & \\
\hline Maximum log SCC > $5.97(930,000 / \mathrm{mL})$ & & 2.28 & 1.26 & 4.15 \\
\hline Minimum $\log \mathrm{SCC} \leq 4.79(62,000 / \mathrm{mL})$ & & Reference & & \\
\hline Minimum log SCC > $4.79(62,000 / \mathrm{mL})$ & & 2.86 & 1.60 & 5.01 \\
\hline Standard deviation $\log \mathrm{SCC}<0.326$ & & Reference & & \\
\hline Standard deviation log SCC $=0.326$ to 0.422 & & 1.97 & 1.09 & 3.49 \\
\hline Standard deviation log SCC $>0.422$ & & 2.54 & 1.30 & 4.87 \\
\hline Random variation & & & & \\
\hline Between-farm variance & 0.36 & & 0.00 & 1.17 \\
\hline
\end{tabular}

did not get CM. This contrasts with the Staph. aureus model, in which increased mean log SCC increased the odds of CM.

There were similarities between the $E$. coli and "no growth" CM models with a positive correlation between maximum log SCC and CM and a negative correlation between mean log SCC and CM. This may have occurred because a significant proportion of "no growth" CM were caused by $E$. coli, with the bacteria not being detected by culture (Zorah et al., 1993). Having controlled for other SCC characteristics, a minimum log SCC $>13,000 / \mathrm{mL}$ was also associated with an increased probability of $E$. coli CM. Therefore, a generally low SCC level over lactation was associated with an increased risk of $E$. coli CM, but not a single low SCC.
Other studies have reported that low SCC is associated with increased rate or severity of CM (Schukken et al., 1999; van Werven 1999; Suriyasathaporn et al., 2000; Peeler et al., 2003; Green et al., 2004), and our results support findings from these studies.

The Strep. dysgalactiae CM model contained only one SCC characteristic, maximum log SCC. Therefore, other than one high SCC, the distributions of SCC during lactation were not different from those of unaffected cows for this pathogen.

The effect of parity on the risk of CM varied for different mastitis pathogens. The risk of $E$. coli $\mathrm{CM}$ was reduced in the first lactation, whereas this was not the case for Staph. aureus CM, when cows of parities 1 and 3 were at the greatest risk. For CM associated with 
Table 6. General linear mixed models for Escherichia coli, and no growth clinical mastitis in data set 3. Parameters were estimated using Markov Chain Monte Carlo with Gibbs sampling.

\begin{tabular}{|c|c|c|c|c|}
\hline & \multirow[b]{2}{*}{ Coefficient } & \multirow[b]{2}{*}{ Odds ratio } & \multicolumn{2}{|c|}{$\begin{array}{l}\text { 95\% Credibility } \\
\text { intervals }\end{array}$} \\
\hline & & & Lower & Upper \\
\hline \multicolumn{5}{|l|}{ Model: $E$. coli clinical mastitis $(\mathrm{n}=310)$} \\
\hline Intercept & -4.56 & & & \\
\hline Parity $>1$ & & Reference & & \\
\hline Parity 1 & & 0.47 & 0.34 & 0.65 \\
\hline Calving September to July & & Reference & & \\
\hline Mean log SCC (unit increase) & & 0.16 & 0.08 & 0.26 \\
\hline Maximum log SCC (unit increase) & & 7.11 & 5.10 & 10.05 \\
\hline Minimum log $\mathrm{SCC} \leq 4.11(13,000 / \mathrm{mL})$ & & Reference & & \\
\hline Minimum log $\mathrm{SCC}<4.11(13,000 / \mathrm{mL})$ & & 0.59 & 0.40 & 0.84 \\
\hline Coefficient of variation $\leq 0.0985$ & & Reference & & \\
\hline Coefficient of variation $>0.0985$ & & 1.20 & 0.82 & 1.73 \\
\hline Calving in February & & 1.60 & 1.01 & 2.47 \\
\hline First lactation in study & & Reference & & \\
\hline Second lactation in study & & 0.30 & 0.05 & 1.13 \\
\hline Parity $>1$ & & Reference & & \\
\hline Parity 1 & & 0.69 & 0.49 & 0.94 \\
\hline Mean log SCC (unit increase) & & 0.45 & 0.29 & 0.73 \\
\hline Maximum log SCC (unit increase) & & 4.07 & 2.77 & 6.06 \\
\hline Random variation & & & & \\
\hline Between-farm variance & 0.77 & & 0.42 & 1.23 \\
\hline
\end{tabular}

Strep. dysgalactiae, parity 3 cows were at reduced risk of CM compared with other cows. The effects of parity and calving season in data set 3 are difficult to explain, but imply that the transmission dynamics were very different between pathogens in these herds. For this study, however, we were concerned with controlling for these processes, thus ensuring that parameter estimates for the SCC variables were unbiased.

Final model parameters were estimated using Monte Carlo Markov Chain with Gibbs sampling. Although relatively new to the veterinary literature, this technique has been successfully employed in the medical and genetic fields (Gilks et al., 1995; Burton et al., 1999). The method was used in the current study because alternative quasi-likelihood approximations, commonly used for hierarchical models with a Bernoulli response variable, can give unreliable parameter estimates or present difficulties with convergence (Snijders and Bosker, 1999; Rasbash et al., 2000). Bayesian techniques offer a useful alternative approach for statistical models incorporating multidimensional, nonnormally distributed data.

Possible methodological sources of error in these data arise from the diagnosis of CM and the accuracy of SCC recording. It is possible that $\mathrm{CM}$ could have been underrecorded during data collection, but is unlikely to have been over-recorded. Misclassification of lactations would generally result in fewer differences in SCC being detected between lactations with and without CM rather than falsely enhancing the differences found. The prospective nature of data collection would have helped to minimize the possibility of incorrect recording. The SCC data were dependent on the accuracy of the electronic counting methods employed by each laboratory. Somatic cell counts from all 3 data sets were estimated by laboratories that were accredited for data collection for national SCC statistics and therefore provide data of equivalent accuracy to those currently used for bull evaluations. It was beyond the scope of this study to assess the reliability of these methods. However, poor accuracy of SCC estimation would, again, have tended to reduce rather than enhance the differences found between lactations with and without CM.

\section{CONCLUSION}

We modeled measures of SCC distributions during lactation to investigate their association with CM. When all pathogens were considered together, results indicated that maximum and standard deviation of log SCC were the best indicators of CM, rather than mean log SCC. Results were consistent across 3 different sets 
of data. Pathogen-specific models indicated that maximum log SCC was consistently positively associated with CM, but that other SCC characteristics differed between pathogens. The models of $E$. coli and "no growth" CM had similar SCC features, including both types showing an increased risk with reducing lactation mean log SCC.

\section{ACKNOWLEDGMENTS}

We would like to thank the farmers and herdspersons involved in the study, the Wood Veterinary Group, Gloucester, UK, and C. Poetzch for collating data set 2. We thank NRS, The Netherlands, for providing milk recording data for data set 3. Financial support came from Leo Animal Health UK Ltd, Milk Development Council, UK, and Roche Vitamins, UK. M. J. Green is supported by a BBSRC case studentship.

\section{REFERENCES}

Barkema, H. W., Y. H. Schukken, T. J. Lam, M. L. Beiboer, G. Benedictus, and A. Brand. 1998. Management practices associated with low, medium, and high somatic cell counts in bulk milk. J. Dairy Sci. 81:1917-1927.

Breslow, N. E., and D. G. Clayton. 1993. Approximate inference in generalized linear mixed models. J. Am. Stat. Assoc. 88:9-25.

Bradley, A. J., and M. J. Green. 2001. Clinical mastitis in six Somerset dairy herds. Vet. Rec. 148:683-686.

Burton, P. R., K. Tiller, L. C. Gurrin, A. W. Musk, W. O. C. M. Cookson, and L. J. Palmer. 1999. Genetic variance components analysis for binary phenotypes using generalized linear mixed models (GLMMs) and Gibbs sampling. Genet. Epidemiol. 17:118-140.

Brooks, S. P., and A. Gelman. 1998. Alternative methods for monitoring convergence of iterative simulations. J. Comput. Graph. Stat. $7: 434-455$.

Clayton, D., and M. Hills. 1993. Statistical Models in Epidemiology. Oxford University Press, Oxford, UK.

Dodd, F. H., D. R. Westgarth, F. K. Neave, and R. G. Kingwill. 1969. Mastitis-The strategy of control. J. Dairy Sci. 52:689.

Emanuelson, U., B. Danell, and J. Philipsson. 1988. Genetic parameters for clinical mastitis, somatic cell counts and milk production estimated by multiple-trait restricted maximum likelihood. J. Dairy Sci. 71:467-476.

Gilks, W. R., S. Richardson, and D. J. Spiegelhalter. 1995. Markov Chain Monte Carlo in Practice. Chapman and Hall, London, UK.

Gonzales, R. N., J. S Cullor, D. E. Jasper, T. B. Farver, R. B. Bushnell, and M. N Oliver. 1989. Prevention of clinical coliform mastitis in dairy cows by a mutant Escherichia coli vaccine. J. Dairy Sci. 53:301-305.

Green, M. J., P. R. Burton, L. E. Green, Y. H. Schukken, A. J. Bradley, E. J. Peeler, and G. F. Medley. 2004. The use of Markov chain Monte Carlo for analysis of correlated binary data: Patterns of somatic cells in milk and the risk of clinical mastitis in dairy cows. Prev. Vet. Med. (accepted)

de Haas, Y., H. W. Barkema, and R. F. Veerkamp. 2002. The effect of pathogen-specific clinical mastitis on the lactation curve for somatic cell count. J. Dairy Sci. 85:1314-1323.

Harmon, R. J., R. J. Eberhart, D. E. Jasper, B. E. Langlois, and R. A. Wilson. 1990. Microbiological Procedures for the Diagnosis of Bovine Udder Infection. Natl. Mastitis Counc. Inc., Arlington, VA.

Hedges, V. J., R. W. Blowey, A. J. Packington, C. J. O'Callaghan, and L. E. Green. 2001. A longitudinal field trial of the effect of biotin on lameness in dairy cows. J. Dairy Sci. 84:1969-1975.
Hosmer, D. W., and S. Lemeshow. 1988. Applied Logistic Regression, Wiley-Interscience, New York, NY.

Kossaibati, M. A., and R. J. Esslemont. 1997. The costs of production diseases in dairy herds in England . Vet. J. 154:41-51.

Lund, M. S., J. Jensen, and P. H. Petersen. 1999. Estimation of genetic and phenotypic parameters for clinical mastitis, somatic cell production deviance and protein yield. J. Dairy Sci. 82:1045-1051.

Mark, T., W. F. Fikse, U. Emanuelson, and J. Philipsson. 2002. International genetic evaluations of Holstein sires for milk somatic cell count and clinical mastitis. J. Dairy Sci. 85:2384-2392.

McCullagh, P., and J. A. Nelder. 1989. Generalized Linear Models. 2nd ed. Chapman and Hall, Oxford, UK.

Milner, P., K. L. Page, and J. E. Hillerton. 1997. The effects of early antibiotic treatment following diagnosis of mastitis detected by a change in the electrical conductivity of milk. J. Dairy Sci. 80:859-863.

Peeler, E. J., M. J. Green, J. L. Fitzpatrick, and L. E. Green. 2003. The association between quarter somatic cell counts and clinical mastitis in three British dairy herds. Prev. Vet. Med. 59:169-180.

Philipsson, J., G. Ral, and B. Bergland. 1995. Somatic cell count as a selection criterion for mastitis resistance in dairy cattle. Livest. Prod. Sci. 41:195-200.

Rasbash, J., W. Browne, H. Goldstein, M. Yang, I. Plewis, M. Healy, G. Woodhouse, D. Draper, I. Langford, and T. Lewis. 2000. A users guide to MlwiN, Version 2.1, Multilevel Models Project, Institute of Education, University of London, UK.

Schukken, Y. H., K. E. Leslie, D. A. Barnum, B. A. Mallard, J. H. Lumsden, P. C. Dick, G. H. Vessie, and M. E. Kehrli. 1999. Experimental Staphylococcus aureus intramammary challenge in late lactation dairy cows: Quarter and cow effects determining the probability of infection. J. Dairy Sci. 82:2393-2401.

Shook, G. E. 1993. Genetic improvement of mastitis through selection on somatic cell count. Vet. Clin. North Am. Food Anim. Pract. 9:563-581.

Shook, G. E., and M. M. Schutz. 1994. Selection on somatic cell score to improve resistance to mastitis in the United States. J. Dairy Sci. 77:648-58.

Shuster, D. E., E. K. Lee, and M. E. Kehlri. 1996. Bacterial growth, inflammatory cytokine production, and neutrophil recruitment during coliform mastitis in cows within ten days after calving, compared with at midlactation. Am. J. Vet. Res. 5711:1569-1575.

Snijders, T., and R. Bosker. 1999. Multilevel analysis: An introduction to basic and advanced multilevel modelling. SAGE publications Ltd, 6 Bonhill St, London, UK.

Spiegelhalter, D., A. Thomas, and N. Best. 2000. WinBUGS Version 1.3. MRC Biostatistics Unit, Institute of Public Health, Robinson Way, Cambridge CB2 2SR, UK.

Suriyasathaporn, W., Y. H. Schukken, M. Nielen, and A. Brand. 2000. Low somatic cell count: A risk factor for subsequent clinical mastitis in a dairy herd. J. Dairy Sci. 83:1248-1255.

Swanson, G. J. T., R. A. Mrode, and C. M. Lindberg. 1998 Genetic progress for production plus health, welfare and profit. Animal Data Centre, Fox Talbot House, Greenways Business Park, Chippenham, Wilts, UK.

van Werven, T. 1999. The role of leukocytes in bovine Escherichia coli mastitis. Ph.D. thesis, University of Utrecht, The Netherlands.

Weiss, W. P. J. S. Hogan, D. A. Todhunter and K. L Smith. 1997. Effect of vitamin E supplementation in diets with a low concentaration of selenium on mammary gland health of dairy cows. J. Dairy Sci. 80:1728-37.

Weller, J. I., A. Saran, and Y. Zeliger. 1992. Genetic and environmental relationships among somatic cell count, bacterial infection and clinical mastitis. J. Dairy Sci. 75:2532-2540.

Zeger, S. L, and M. R. Karim. 1991. Generalized linear models with random effects: a Gibbs sampling approach. J. Am. Stat. Assoc. 86:79-86.

Zorah, K. T., R. C. Daniel, and A. J. Frost. 1993. Detection of bacterial antigens in milk samples from clinical cases of bovine mastitis in which culture is negative. Vet Rec. 27:208-210. 